\title{
Vegetation degradation assessment in the agricultural zone of Northern Mongolia
}

\section{Оценка деградации растительного покрова в сельскохозяйственной зоне Северной Монголии}

\author{
Otgontseteg D. ${ }^{1}$, Bayasgalan D. ${ }^{2}$, Enerel T. ${ }^{1}$, Khaulenbek A. ${ }^{1}$ \\ Отгонцетег Д. ${ }^{1}$, Баясгалан Д. ${ }^{2}$, Энерел Т. ${ }^{1}$, Хауленбек А. ${ }^{1}$ \\ ${ }^{1}$ Institute of Geography and Geoecology, Mongolian Academy of Sciences, Ulaanbaatar, Mongolia. \\ E-mails: otgondn@gmail.com; Enerel0218@gmail.com; a.khaulenbek@gmail.com \\ ${ }^{1}$ Институт географии и геоэкологии Академии наук Монголии, г. Улан-Батор, Монголия \\ ${ }^{2}$ Plant researcher,PhD, Ulaanbaatar, Mongolia.E-mail:sado_0308@yahoo.com \\ ${ }^{2}$ Исследователь ботаник, г. Улан-Батор, Монголия
}

\begin{abstract}
Summary. We conducted research to assess vegetation degradation in Selenge province described as the agricultural zone. Our research results based on the vegetation community map showed that $46.7 \%$ of the total area is light, $3.3 \%$ is moderate, $13.9 \%$ is strong, and $30.4 \%$ is very strong degraded. Vegetation degradation was mostly observed in river valleys, lower plains, hills and small mountains and mountain slopes due to the intensity of summer grazing. The moderately degraded area was often winter places using as rotate or properly managed grazing land and light degradation has occurred in the forest area. Very strong degradation was revealed mainly in Saikhan, Orkhon, Javkhlant sub-provinces and strongly degraded in Sant, Orkhontuul, Baruunburen. Light degradation of vegetation were observed in sub-provinces adequately covered by forest including Eruu, Tushig, Shaamar, Khuder, but there are still problems related to mining and deforestation.
\end{abstract}

Key words. Arable land, grazing, vegetation degradation, Mongolia, Selenge.

Peферат. Проведено исследование по оценке деградации растительного покрова в провинции Селенга, являющейся сельскохозяйственной зоной. Результаты наших исследований, основанные на картировании, показали, что 46,7 \% общей площади растительных сообществ деградировано в легкой степени, 3,3 \% - в умеренной, $13,9 \%$ - в сильной, 30,4 \% - в очень сильной. Деградация растительного покрова наблюдалась в основном в долинах рек, в понижениях, на холмах и горных склонах из-за интенсивного летнего выпаса скота. Умеренно деградированные территории часто представляют собой зимники, используемые в качестве чередующихся или правильно управляемых пастбищных земель, а также легкая степень деградации отмечена в лесной зоне. Очень сильная деградация растительности была выявлена в основном в субпровинциях Сайхан, Орхон, Джавхлант, а сильно деградированные участки в Сант, Орхонтуул, Баруунбурен. Легкая степень деградации растительности наблюдалась в субпровинциях с лесным растительным покровом, включая Эруу, Тушиг, Шаамар, Худер, но там, тем не менее существует проблема, связанная с добычей полезных ископаемых и вырубкой леса.

Ключевье слова. Выпас скота, деградация растительности, Монголия, пахотные земли, Селенга.

Introduction. There are three main vegetation zones (forest, steppe, desert) that occurred from north to south of the Mongolia due to topographical gradient and arid climatic condition from the central continental position and far from oceanic influence (Ulziikhutag, 1989). In Selenge province, our study area, there are taiga on the east, forest on the north-west, mountain steppe at branch mountains, steppe in the small hills and plains and meadow in the river valleys. However, the total area of this province is $2.7 \%$ of the Mongolian territory, there are $10 \%$ of total forest resources and big rivers including Selenge, Orkhon, Kharaa, Eruu flowing through the territory.

Climate change and human actions both have negative effects on the land cover of the Mongolia and accelerating land degradation (Batkhishig, 2013). Over the past eight decades, the annual average temperature 


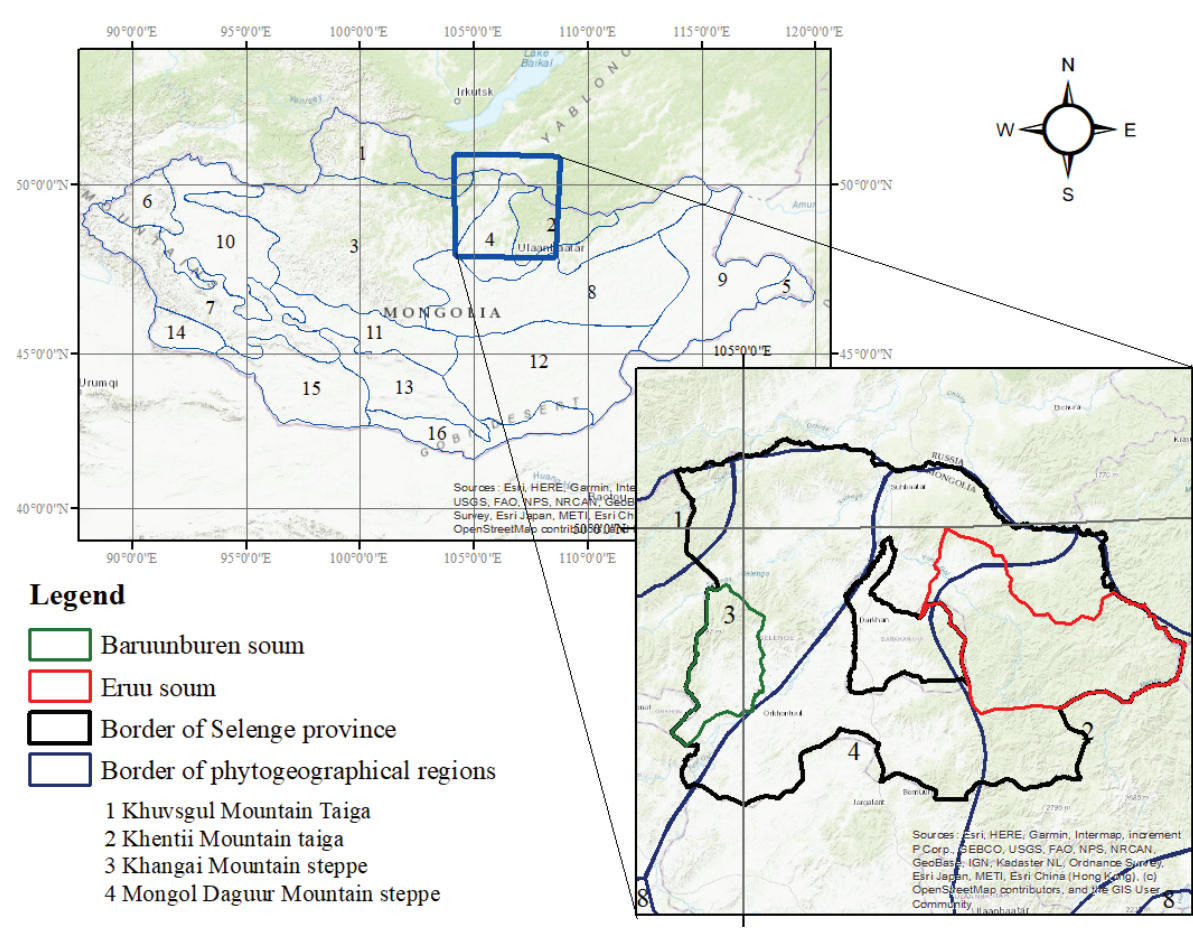

Figure 1. Study area. is warming regionally by 3-4 ${ }^{\circ} \mathrm{C}$, surface evaporation rate has increased by $2.9 \mathrm{~mm} /$ year while precipitation has decreased by $0.3 \mathrm{~mm} /$ year since 1961 at the Baruunkharaa meteorological station (Desertification report, 2021). The increasing heat is effective to activate plant photosynthesis in this area, but it may plant to undergo heat stress due to increasing overheat frequency. For instance, the average number of days observed overheating was 13.8 days in 1961-1990, it became 25.5 days in 19912015 (Desertification report, 2021). The rising air temperature and declining precipitation during the warm season are reasons to increase aridity in this region.

Overgrazing and agricultural expansion are the main factors to involve human-induced land degradation and it has took 70 percent of cause of land degradation in arid land all over the world (Ravi et al., 2009). In Selenge province, type of land use is variable and more intensive compared to other provinces of the Mongolia. In accordance with the Mongolian governmental order on $16 \mathrm{May}$, 2018 named "To determine some agricultural zone", 44 subdivisions of 16 sub-provinces in Selenge were described to activate agriculture with intensive livestock farming bring together to coordinate with local development policy and general plan. However, livestock number is increasing continuously while grazing land area had been declining in last twenty years. Livestock number had increased by 1.1 million in standard sheep head or 69.5 percent in Selenge since 1990. Arable land had increased by $0.13 \%$ in the last decade and it is situated mostly in Saikhan, Orkhon, Orkhontuul, Javkhlant, Zuunburen sub-provinces. Over half of the total area of Selenge province is agricultural land (50.6\%), $43.6 \%$ is forest and others are settled area, road, industries and mining area.

The most common type of land degradation in arid land is composition change in vegetation community and it can be an indicator to detect land degradation (Bunning et al., 2011). This adverse state such as digression species introduced in the vegetation communities and decreased participation of palatable plant species observed commonly in Selenge. We aimed to (1) assess vegetation degradation degree, (2) determine the distribution of degraded land, (3) evaluate the total area of degraded land.

Study area. The annual average temperature was recorded $(-0,23)-(+0,1){ }^{\circ} \mathrm{C}$ in $1961-1990,(-0,22)-$ $(+1){ }^{\circ} \mathrm{C}$ in 1981-2010, $(-1,2)-(+1)^{\circ} \mathrm{C}$ in 1991-2019 respectively. The precipitation was $400 \mathrm{~mm}$ at high mountain region, 275-300 $\mathrm{mm}$ at Orkhon-Selenge valley, 300-350 $\mathrm{mm}$ at hills and small mountainous area (Report on desertification..., 2021). According to phyto-geographical classification of Mongolia by Grubov and Yunatov (1952), 4 regions are presented in Selenge province - Khuvsgul and Khentii mountain taiga, Khangai forest steppe and Mongol Daguur mountain steppe (fig. 1). We chose 2 sub-provinces that belong to different phyto-geographical regions to illustrate vegetation degradation in detail (Baruunbvren in Khangai, Eruu in Khentii, Mongol Daguur).

Eruu is the biggest sub-province and its most part is covered by forest, which accounts for $35.3 \%$ of total forest resources in Selenge. Meadow with Kobresia bellardii (All.) Degl., Carex rupestris Bell. ex All., Carex stenocarpa Turcz. ex V. Krecz. is distributed at top of high mountains, lawn meadow with Forb-gramineum-various shrub along to rivers flowing between mountains, meadow steppe with Artemisia frigida Willd., Agropyron cristatum (L.) P.B., Cleistogenes squarrosa (Trin.) Keng., Lespedaza hedysaroides (Pall.) Kitag., Stipa baicalen- 


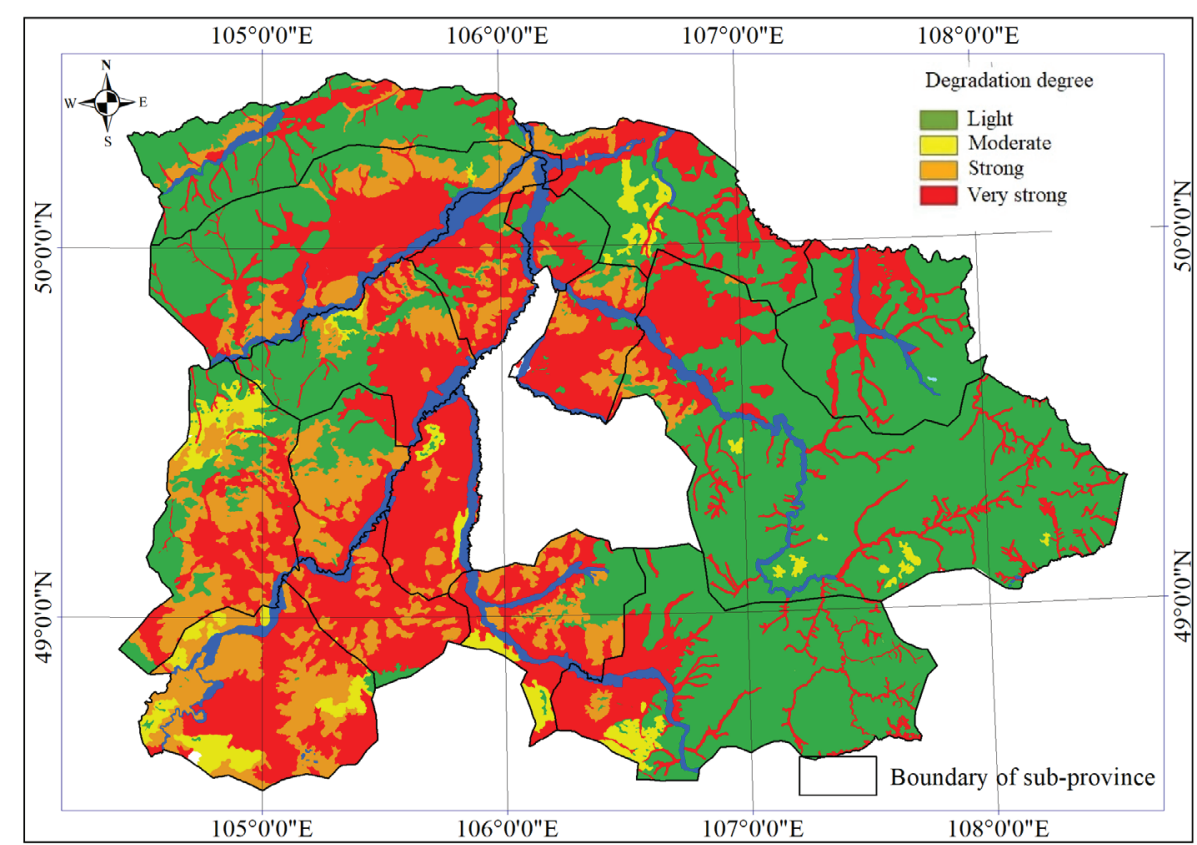

Figure 2. Vegetation community degradation of Selenge province. sis Roshev. in northern part of sub-province and steppe with Stipa krylovii Roshev., Stipa sibirica (L.) Lam., Poa attenuata Trin., Cleistogenes squarrosa, Koeleria macrantha L., Agropyron cristatum at low plains alongside of Eruu river.

Baruunburen has a relatively small forest area which is equivalent to only $5 \%$ of total resources in Selenge. Forb-Betula plathyphylla Sukacz.-Larix sibirica Ldb. forest is distributed at mountains in the middle and northern part of sub-province, mountain meadow steppe with Forb-Festuca sibirica Hack. ex Boiss., Stipa baicalensis, and meadow steppe with forb-Poa attenuata-Stipa baicalensis at upper

and lower slope of mountains. Mountain steppe with forb-Amygdalus pedunculata Pall.-Filifolium sibiricum Kitam. is distributed at mountains in the south, meadow with forb-gramineum-various shrub species along small rivers between mountains and steppe with forb-small gramineum-Stipa krylovii is distributed on plains.

Materials and methods. The vegetation community map of Selenge province was made using 1:200000 scale topographic map and vegetation map of Mongolia. We conducted fieldwork during last 10 days of August 2020. Plant species and their cover were recorded using $1 \mathrm{~m}^{2}$ quadrat at each vegetation community with several

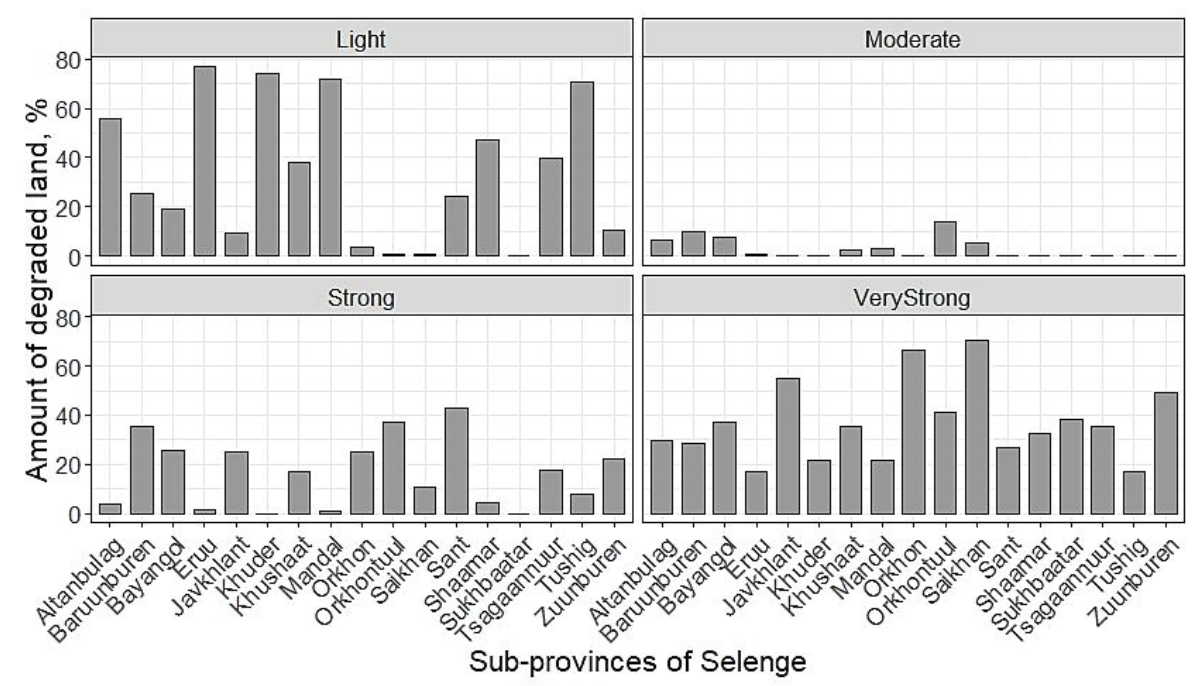

Figure 3. Amount of degraded area of sub-provinces in Selenge. repitition. Plant species were determined according to key to the vascular plants of Mongolia (Grubov, 2008; Ulziikhutag, 1985). Then degradation degree was evaluated based on digression species composition and their cover as formula 1 . Index is $0<\mathrm{K}<1,0-0.2$ is very strong, $0.3-0.4$ is strong, $0.5-0.7$ is moderate, $0.8-1$ is light or absence of degradation represent separately.

Vegetation degrada-

tion $K=\frac{a-\sigma}{a+6}$

a-total cover, 6-cover of digression species.

According to LADA (Land Degradation Assessment in Drylands), I. Tuvshintogtokh (2014), G. Tserenbaljid (2002), O. Chognii (1981), digression species were determined. The dominance of these species can reveal degradation, however distributed typically 


\section{Vegetation degradation in Baruunburen}

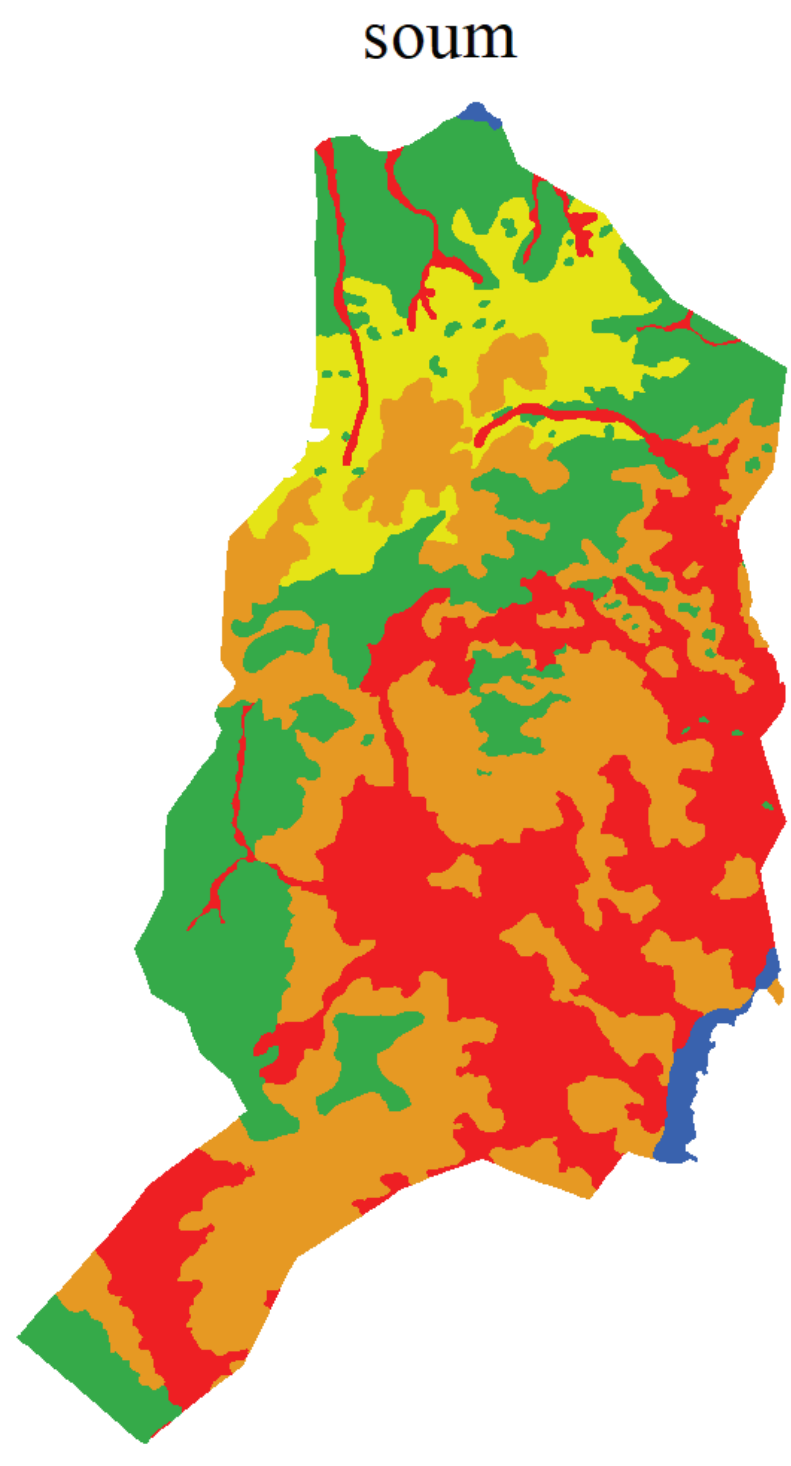

in steppe and desert steppe. Degradation map of vegetation community was made based on degradation degree index and converted in proportion after their overall area was calculated using ArcGIS 10.2.

Results. Our research result showed that $46.7 \%$ of the total area is light, $3.3 \%$ is moderate, 13.9 $\%$ is strong, $30.4 \%$ is very strong degraded (fig. 2). We described cropland as very strong degraded and forest area as lightly degraded. Very strong degradation of vegetation community was observed in Saikhan, Orkhon, Javkhlant sub-provinces and it reached 54-70 percent of the total sub-province area. In addition, 35-43 percent of the total area of sub-provinces such as Sant, Orkhontuul, Baruunburen classified as strongly degraded. Light degradation was observed at part with forest area such as Eruu, Khuder, Mandal, Tushig and 70-76 percent of total area was lightly degraded and 17-21 percent was strongly degraded area (fig. 3). Moderately degraded area was often recorded at winter places with rotate or properly managed grazing land.

Typically, vegetation degradation was detected mainly at low hills, small mountains, valleys, plains between these mountains, and meadow along rivers. In general, Carex duriuscula
C.A. Mey. dominated and cover of digression species such as Potentilla bifurca L., Lepidium ruderale L., Plantago major L., Amaranthus retroflexus L., Urtica cannabina L., Taraxacum officinale Wigg. tended to increase in river valleys and meadow along small rivers. Therefore digression species such as Cleistogenes squarrosa, Elymus chinensis (Trin.) Keng., Artemisia adamsii Bess. at lower plains and mountain dry valleys, Potentilla acaulis L., A.frigida, A.scoparia Waldst.et Kit., Heteropappus hispidus (Thunbg.) Less. at mountain lower slope and small hills encroached aggressively and participation of main species in community were decreased.

\section{Baruunburen sub-province}

For Baruunburen, strong degradation was detected in meadows along rivers, valleys between mountains by reason of overgrazing and agricultural activity (fig. 4). Potentilla bifurca-Carex duriuscula community with $40-79 \%$ coverage, $10-11$ species $/ \mathrm{m}^{2}$ was formed along small rivers between mountains. At sparsely veg- 


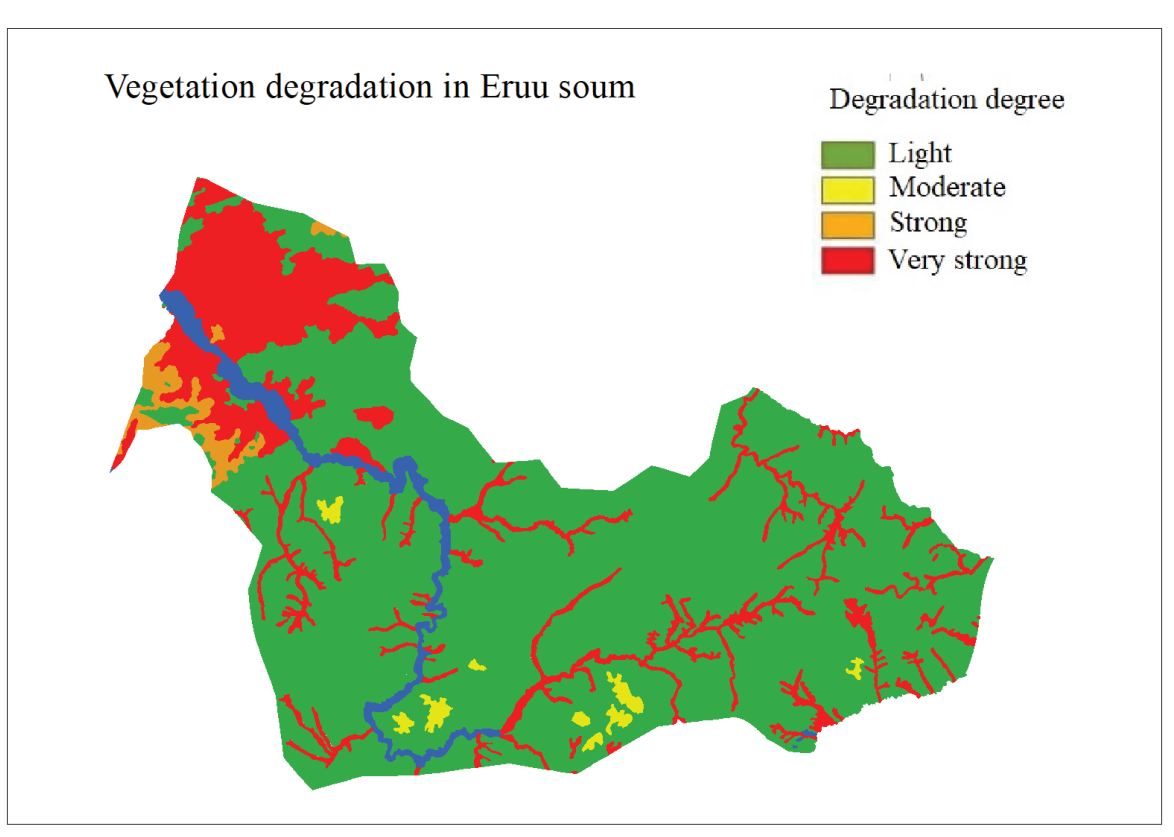

Figure 5. Vegetation degradation in Eruu sub-province. etated part, Potentilla acaulis-Carex duriuscula community with $23-35 \%$ coverage, $8-10$ species $/ \mathrm{m}^{2}$ was recorded. Plant heights were $2-6 \mathrm{~cm}$ throughout the community. Vegetation degradation indexes were $0.01-0.03$ or very strong. 4 individuals of Cleistogenes squarrosa from dry steppe were counted in $1 \mathrm{~m}^{2}$, tussock sizes were $5^{\star} 2 \mathrm{~cm}, 4^{\star} 6 \mathrm{~cm}$, and heights were $1-2 \mathrm{~cm}$.

Carex duriuscula-Artemisia frigida or Carex duriuscula-Artemisia adamsii communities with 23-48\% coverage, 6-7 species $/ \mathrm{m}^{2}$, in some cases only $A$. adamsii distributed through large valleys and small mountains. Stipa krylovii and Agropyron cristatum which are main species of community occupied only 0.5-3\%. Carex duriuscula-Potentilla acaulis community with $80 \%$ coverage, 11-12 species $/ \mathrm{m}^{2}$ occur at the lower slope of small mountains and participation of several forbs such as Artemisia frigida, Areniaria capillaris Poir. increase in the community at upper slope. Vegetation degradation indexes were $0.01-0.02$ or very strong. Plant heights were 6-10 cm for Stipa krylovii, Carex duriuscula, Allium sp. and 2-6 cm for others. Tussock sizes were $2^{\star} 3 \mathrm{~cm}, 5^{\star} 4 \mathrm{~cm}$ for Arenaria capillaris, $4^{\star} 3 \mathrm{~cm}, 3{ }^{\star} 1 \mathrm{~cm}$ for Cleistogenes squarrosa, $3 * 2 \mathrm{~cm}, 2^{\star} 1 \mathrm{~cm}, 4^{\star} 5 \mathrm{~cm}$ for Stipa krylovii, $2^{\star} 1 \mathrm{~cm}$ for Agropyron cristatum.

Vegetation degradation was relatively moderate in mountain steppe under the rotational grazing. Artemisia laciniata Willd.- Stipa krylovii mountain steppe community with $90 \%$ coverage, 22 species $/ \mathrm{m}^{2}$ was distributed around winter places free from grazing during summer time. There were observed dominance of Stipa krylovii and sub-dominance of Elymus chinensis, Agropyron cristatum and various forbs. Digression species such as Elymus chinensis, Thermopsis dahurica Czefr., Heteropappus hispidus, Artemisia frigida, Potentilla bifurca, P. acaulis, Cleistogenes squarrosa, Veronica incana L. composed 1-5 \% of total coverage. Plant heights were $2-6 \mathrm{~cm}, 6-18 \mathrm{~cm}$ for forbs, $20-32 \mathrm{~cm}$ for gramineum. Vegetation degradation indexes were $0.5-0.7$ or moderate. Compared to grazed community, vegetation degradation indexes were $0.08-0.1$ or very strong under grazing effect. In this community, Carex duriuscula and Artemisia frigida dominated and recorded 30-42 \% coverage, 7 species $/ \mathrm{m}^{2}$ at upper slope of mountain located at Orkhon river valley whereas main species of community occupied 0.5-6\%. Plant heights were 3-8 cm for A. frigida, C. squarrosa, A. cristatum, C. duriuscula, 10-23 cm for S. krylovii, Caragana stenophylla Pojark., H.hispidus.

\section{Eruu sub-province}

Meadow steppe and steppe in northern part were degraded strongly under human activities as well as mining, deforestation, and road building in forest area adversely effect on the environment (fig. 5). Forb-Artemisia scoparia-Carex duriuscula community with 97-99 \% coverage, 13-14 species $/ \mathrm{m}^{2}$ distributed along the river valley and Plantago major, Achillea asiatica Serg. and Elymus chinensis get sub-dominance in patch. Vegetation degradation indexes were $0.03-0.2$ or very strong. Plant heights were $6-10 \mathrm{~cm}$ for general. We observed this vegetation community state very commonly at meadow in large valleys between mountains.

We described that forest area has light degradation, because of restoration in the forest was considered as presumptive even though underwent land use activities. But there was degradation at forest edge under grazing effect. Stipa baicalensis-Artemisia laciniata-Carex pediformes C. A. Mey. community with 64-69 \% coverage, 13-17 species $/ \mathrm{m}^{2}$ was distributed at mountain upper slope of forest edge. Vegetation degradation indexes were 0.5-0.8 or moderate and light. Plant heights were 10-14 cm for Carexpediformes, 25-32 cm for Artemisia lacinia- 
ta, 36-53 cm for Stipa baicalensis, $8-18 \mathrm{~cm}$ for other forbs. Digression species - Potentilla acaulis formed patches measured $633^{\star} 28 \mathrm{~cm}, 36^{\star} 21 \mathrm{~cm}, 30^{\star} 13 \mathrm{~cm}, 38^{\star} 64 \mathrm{~cm}, 75^{\star} 34 \mathrm{~cm}, 55^{\star} 21 \mathrm{~cm}, 75 * 38 \mathrm{~cm}$, height was $2-4 \mathrm{~cm}$. Artemisia frigida-Agropyron cristatum community with $50 \%$ coverage, 9 species $/ \mathrm{m}^{2}$ was distributed near to cropland and dominated by Agropyron cristatum as well as several digression species with $4-8 \%$ coverage. Vegetation degradation index was 0.4 or strong. Plant heights were $7-10 \mathrm{~cm}$ for forbs, $10-28 \mathrm{~cm}$ for $A$. cristatum, A. frigida, Galium verum L. Potentilla acaulis formed patches $13^{\star} 10 \mathrm{~cm}, 11^{\star} 14 \mathrm{~cm}, 27{ }^{\star} 14 \mathrm{~cm}$ and height was $2-4 \mathrm{~cm}$.

Discussion. It is clear that land degradation is becoming disturbant in Mongolia and early detection of land degradation is vital in arid and semi-arid ecosystems. Anthropogenic factors including mining, road erosion, overgrazing, agricultural soil erosion, and soil pollution which intensify the land degradation process, all have adversely impact on the environment.

We considered cropland as very strong degraded, because vegetation cover is eroded under the influence of technical activities during ploughing and vegetation primary state is lost. Therefore, that topsoil became more prone to erosion by wind and water is a condition to activate land degradation. During our study, this condition observed commonly in Baruunkharaa, Altanbulag, Zuunburen, Tsagaannuur, Khutul, Orkhon, Orkhontuul, Javkhlant, Zuunkharaa where agricultural intensity is high. Also very strong and strong degradation were recorded at low hills, small mountains, valleys, plains between these mountains, and meadow along rivers associated with grazing effect. For Selenge province, using $39.5 \%$ of the total area as pasture land is relation to large area of the forest resource. $20 \%$ of the total area was used as pasture in some sub-provinces such as Altanbulag, Eruu, Mandal, Khuder, Tushig, Shaamar where covered largely by forest. However, the amount of degraded land is lower in these sub-provinces compared to others, grazing effect was more severe along small rivers that are waterheads of large rivers. Very strong and strong degradation were mainly recorded in Orkhon, Orkhontuul, Saikhan, Zuunburen, Baruunburen, Bayangol subprovinces and it was explained by $80 \%$ of the total area of sub-provinces used as pasture. Specially, due to grazing is concentrated along river valleys during summer time, vegetation cover in meadow and marsh was overgrazed and become cause of vegetation composition change and aboveground biomass reduction. Although we assumed light degradation in the forest, deforestation, mining activity (particularly in Eruu) and forest fire are big issues. In addition, road erosion related to mining and logging was a problem to consider inevitably.

To mitigate these adverse effects on the environment, required activities should be carrted out. We suggested recommendations including free from grazing in some areas, planting by perennials to restore ruined cropland, establishing a greenbelt to protect soil erosion and fencing pasture land and improving grazing land by perennials.

Acknowledgement. This study was implemented in Institute of Geography and Geoecology within project named "Desertification assessment of Selenge province and management plan to mitigate desertification" funded by Selenge province. We appreciate to all researchers of Division of Desertification Study and local community encouraged in many ways.

\section{REFERENCES}

Batkhishig O. Human Impact and Land Degradation in Mongolia. Chapter 12. In The volume -Dry land East Asia: Land Dynamics Amid Social and Climate Change. Ecosystem Science and application. - The Higher Education Press, 2013. - P. 265-282.

Bunning S., McDonald J., Rioux J. Land degradation assessment in drylands: Manual for local level assessment of land degradation and sustainable land management, Part2. Food and Agriculture Organization Of The United Nations. - Rome, 2016. - P. 39- 65 .

Chognii O. Basic principle on change and restoration of pasture in Eastern Khangai // Floral kingdom and vegetation research of Mongolian People's Republic, II. - Ulaanbaatar, 1981. - P. 179-300.

Report on desertification: Land degradation and desertification assessment of Selenge province and management plan to mitigate // Research report, Institute of Geography and Geoecology, MAS. -Ulaanbaatar, 2021. - P. 59-69.

Grubov V. I. Key to the vascular plants of Mongolia. - Ulaanbaatar: Gan print, 2008. - P. 22-324.

Grubov V. I., Yunatov A. A. Main pecularities of flora of the MPR in relation to its regionalization // Botanicheskiy Zhurnal, 1952. - № 37. - P. 45-64.

Ravi S., Breshears D. D., Huxman T. E., D'Odorico P. Land degradation in drylands: Interactions among hydrologicaeolian erosion and vegetation dynamics // Geomorphology, 2010. - Vol. 116(3-4). - P.236-245. 
Tuvshintogtokh I. Vegetation of Mongolian steppe. - Ulaanbaatar, 2014. - P. 42-47.

Tserenbaljid G. Photos of weeds distributed in the Mongolia. - Ulaanbaatar: Admon print, 2002. - P. 251.

Ulziikhutag N. Forage plant species of the Mongolian People's Republic. - Ulaanbaatar, 1985. -P. 150-283.

Ulziikhutag N. Floral outline of Mongolia. - Ulaanbaatar: Mongolian State publishing, 1989. - P. 15. 